\title{
Biochemical characterization of an anti-Candida factor produced by Enterococcus faecalis
}

\author{
Raeesh M Shekh and Utpal Roy*
}

\begin{abstract}
Background: Because Candida albicans is resistant to several antifungal antibiotics, there is a need to identify other less toxic natural products, particularly antimicrobial proteins, peptides or bacteriocin like inhibitory substances. An attempt has been made to purify and characterise an anti-Candida compound produced by Enterococcus faecalis.

Results: An anti-Candida protein (ACP) produced by E. faecalis active against 8C. albicans strains was characterised and partially purified. The ACP showed a broad-spectrum activity against multidrug resistant C. albicans MTCC 183, MTCC 7315, MTCC 3958, NCIM 3557, NCIM 3471 and DI. It was completely inactivated by treatment with proteinase $\mathrm{K}$ and partially by pronase $\mathrm{E}$.

The ACP retained biological stability after heat-treatment at $90^{\circ} \mathrm{C}$ for 20 min, maintained activity over a pH range 6-10, and remained active after treatment with a-amylase, lipase, organic solvents, and detergents. The antimicrobial activity of the $E$. faecalis strain was found exclusively in the extracellular filtrate produced in the late logarithmic growth phase. The highest activity $\left(1600 \mathrm{AU} \mathrm{mL}^{-1}\right)$ against $C$. albicans MTCC 183 was recorded at $48 \mathrm{~h}$ of incubation, and activity decreased thereafter. The peptide showed very low haemagglutination and haemolytic activities against human red blood cells. The antimicrobial substance was purified by salt-fractionation and chromatography.

Partially purified ACP had a molecular weight of approximately $43 \mathrm{KDa}$ in Tricine-PAGE analysis. The 12 amino acid $\mathrm{N}$ terminal sequence was obtained by Edman degradation. The peptide was de novo sequenced by ESI-MS, and the deduced combined sequence when compared to other bacteriocins and antimicrobial peptide had no significant sequence similarity.
\end{abstract}

Conclusions: The inhibitory activity of the test strain is due to the synthesis of an antimicrobial protein. To our knowledge, this is the first report on the isolation of a promising non-haemolytic anti-Candida protein from E. faecalis that might be used to treat candidiasis especially in immunocompromised patients.

Keywords: Antimicrobial peptides, Antimycotic peptides, Anti-Candida, AMP, Enterococcus faecalis

\section{Background}

Antimicrobial and antimycotic peptides are small cationic and amphipathic molecules, generally with fewer than 50 amino acids. These ubiquitous peptides have been isolated from prokaryotes and eukaryotes in the plant, bacterial, fungal, and animal kingdoms [1,2]. Nature has strategically placed antimicrobial and antifungal peptides as a first line of defence between the host

\footnotetext{
* Correspondence: utpalroy@gmail.com

Department of Biological Sciences, Birla Institute of Technology and Science (BITS) Pilani KK Birla Goa Campus, NH-17B, Goa 403726, India
}

organism and its surrounding environment, because these peptides are able to inhibit quickly a wide spectrum of infectious microbes without significant toxicity to the host organism. When insects are infected within a short period they secrete an array of cationic peptides to combat the invading organism [3]. Although antimicrobial peptides (AMP) are the primary means of combating organisms in lower forms of life, these peptides have an adjunct role in the immune system of phylogenetically more advanced organisms.

There is a large array of antifungal proteins with different structures. In addition to the well-known glucanases

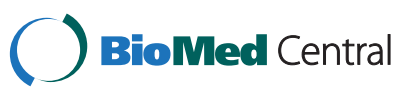

(C) 2012 Shekh and Roy; licensee BioMed Central Ltd. This is an Open Access article distributed under the terms of the Creative Commons Attribution License (http://creativecommons.org/licenses/by/2.0), which permits unrestricted use, distribution, and reproduction in any medium, provided the original work is properly cited. 
[4], chitinases [5], thaumatin-like proteins [6], defensins [7] and ribosome-inactivating proteins [8], there is a diversity of other antifungal proteins such as lipid transfer proteins [9] and protease inhibitors [10].

Both fungi and humans are eukaryotes and at the molecular level, their cells are similar. This makes it more difficult to find or design drugs that target fungi without affecting human cells. Consequently many antifungal drugs cause side effects. Some of these side effects can be life threatening if the drugs are not used properly. Despite chemical therapies, serious fungal infections remain difficult to treat, and resistance to the available drugs is emerging [11]. Antifungals work by exploiting differences between mammalian and fungal cells to kill the fungal organism without dangerous effects on the host. A common theme with most of these widespectrum AMPs is that they lyse the cell membranes of the pathogens without harming the host targets. Despite this non-specific mechanism, many of these peptides do not lyse mammalian membranes at concentrations that can inhibit the pathogen [12].

In the last decades, the incidence of fungal infections by pathogenic $C$. albicans and other related human opportunistic yeast species has increased dramatically due to the rise in the number of immunocompromised patients. Several Candida species especially C. albicans normally inhabit the oral cavity, respiratory and intestinal tracts, and vaginal cavity of humans and animals. In recent years, there has been a marked increase in the incidence of treatment failures in candidiasis patients receiving long-term antifungal therapy, which has posed a serious problem in its successful use in chemotherapy. Candida cells acquire multidrug resistance (MDR) during the course of the treatment [13].

Many bacterial strains, and particularly their enzymes, that perform catalysis efficiently at low temperatures are used in a number of biotechnology applications [14]. Enterococci, as part of the natural intestinal flora of humans and animals, are known to play an important role in maintaining microbial balance $[15,16]$. Many different enterocins have been described from Enterococcus faecalis and E. faecium. Some of these peptides showed activity against Escherichia coli [17] and Salmonella pullorum [18].

Since the literature on bacterial antifungal proteins is rather scanty compared with that on bacterial bacteriocins, there is a pressing need to explore and isolate from new sources potential bacteria capable of producing novel AMPs and to characterise them for further applications. In the present study, we report the purification and characterisation of an antifungal protein produced by E. faecalis, that shows broad-spectrum activity against the indicator organisms, multidrug resistant C. albicans with negligible haemolytic activity.

\section{Results}

\section{Characterization of species}

The promising anti-mycotic strain in the present study was determined to be gram-positive cocci, acid producing, non-motile, catalase and oxidase negative. The strain showed good growth at $6.5 \%(\mathrm{w} / \mathrm{v}) \mathrm{NaCl}$ at 14 and $37^{\circ} \mathrm{C}$. In addition it was esculin hydrolysis-positive as it fermented mannose which is the characteristic of the genus Enterococcus. The producer of the anti-mycotic principle was identified as Enterococcus faecalis based on its physiological and biochemical characteristic. Based on the $16 \mathrm{~S}$ rDNA gene sequence, the strain was identified as E. faecium [19]. Further, using the primers EM1A and EM1B [20], an amplicon of approximately 685 base pairs was observed on $1.2 \%(\mathrm{w} / \mathrm{v})$ agarose gel confirming the strain to be E. faecium. However, this strain reduced potassium tellurite and produced black colour colonies, indicating the species E. faecalis.

The two wild type isolates (DI and WI) of the pathogenic indicator organism were identified as C. albicans based on $18 \mathrm{~S}$ ribotyping. The sequences of the DI and WI isolates showed closest homology (99\%) to the sequences of $C$. albicans M60302.YSASRSUA and AJ005123, respectively.

\section{Determination of inhibitory spectrum}

The susceptibilities of various multidrug resistant C. albicans strains to growth inhibition by the supernatant as well as dialysed concentrate of E. faecalis are presented in Table 1. The supernatant and dialysed concentrate also showed inhibitory activity against one wild type $C$. albicans strain (DI) isolated from a diabetic patient from Goa. Amongst these strains, maximum activity was observed against C. albicans strains MTCC 183, MTCC 3958, MTCC 7315, and NCIM 3471 and minimum activity was observed against wild type C. albicans (DI) (Figure 1a, b, c) and C.krusei (data not shown). The biological activity of ACP at different dilutions is shown in Figure 1 ( $\mathrm{d}$ and e) against MTCC 183.

\section{Antimicrobial activity of cell wall and cytoplasmic extracts}

The antimicrobial activity of the cell wall and cytoplasmic extracts of $E$. faecalis was determined using a cutwell agar assay on MGYP and BHI plates. No zone of inhibition was produced against C. albicans MTCC 3958, Pseudomonas aeruginosa MTCC 741 and Staphylococcus aureus MTCC 737 by cell wall and cytoplasmic extracts, establishing that the inhibition was mainly due to extracellular substances.

\section{Kinetics of antifungal protein production}

Biomass and antimycotic protein production by E. faecalis in modified trypticase soya (mTS) broth, was analysed at 
Table 1 Inhibitory spectrum of anti-Candida protein ACP against different indicator organisms

\begin{tabular}{llll}
\hline Strain & Identified organisms & Indicator organisms & Zone of inhibition \\
\hline 210 & E. faecalis & Yersinia intermedia (AGM 108-5) & $25 \mathrm{~mm}$ \\
& & Candida albicans & $>18 \mathrm{~mm}$ \\
& $($ NCIM 3471, MTCC183, MTCC 7315, & \\
& MTCC 227 and MTCC 3958) & $55 \mathrm{~mm}, 47 \mathrm{~mm}$ \\
& Dialysed Concentrate & MTCC183 and MTCC 7315 & $13 \mathrm{~mm}$ \\
\hline
\end{tabular}

the incubation temperature of $14^{\circ} \mathrm{C}$ (Figure 2). This strain reached the stationary phase after $20 \mathrm{~h}$. Prolonged incubation up to $56 \mathrm{~h}$ promoted degradation of the ACP but no lysis of biomass. No ACP was produced within $8 \mathrm{~h}$ at $14^{\circ} \mathrm{C}$, but it was produced during the active growth phase, and its concentration reached a maximum at $48 \mathrm{~h}$, at the middle of the maximum stationary phase. The highest activity (1600 AU mL $\mathrm{m}^{-1}$ ) against C. albicans (MTCC 183) was recorded between 44-48 $\mathrm{h}$ of incubation and decreased thereafter. The $\mathrm{pH}$ dropped rapidly during the exponential phase, probably because of the strong production of acid associated with growth.

\section{Effects of heat, pH, and Hydrolytic Enzymes}

The activity of the cell-free supernatant (CFS) was stable upon treatment at different temperatures, for up to $90^{\circ} \mathrm{C}$ for $20 \mathrm{~min}$, but the activity was lost completely after boiling and autoclaving (Table 2). The antimycotic property of the CFS also remained unaffected at the $\mathrm{pH}$ range of 6.0-8.0. However, at $\mathrm{pH}$ values of 5.0 and 9.0 the activity was reduced by $50 \%$, whereas at $\mathrm{pH}$ values of 2.0, 4.0 and 10.0 the activity was completely lost. The ACP was sensitive to different proteolytic enzymes (proteinase $\mathrm{K}$ and pronase $\mathrm{E}$ ) confirming its proteinaceous nature whereas it was resistant to pepsin, $\alpha$-amylase, lipase, lysozyme and trypsin at the concentration of $1.0 \mathrm{mg} \mathrm{mL}^{-1}$ (Table 2).

\section{Effects of surfactants, organic solvents and storage}

The antimycotic peptide ACP remained fully active when treated with different surfactants and organic solvents as mentioned in 'Methods'. The activity was enhanced by $33.4 \%$ in the presence of SDS $(1.0 \% \mathrm{w} / \mathrm{v})$ (Table 2). Long-term storage (1 year) at $-80^{\circ} \mathrm{C}$ did not affect the antimicrobial activity (98\%), but a slight reduction (20\%) in activity at $4^{\circ} \mathrm{C}$ and $-20^{\circ} \mathrm{C}$ was found.

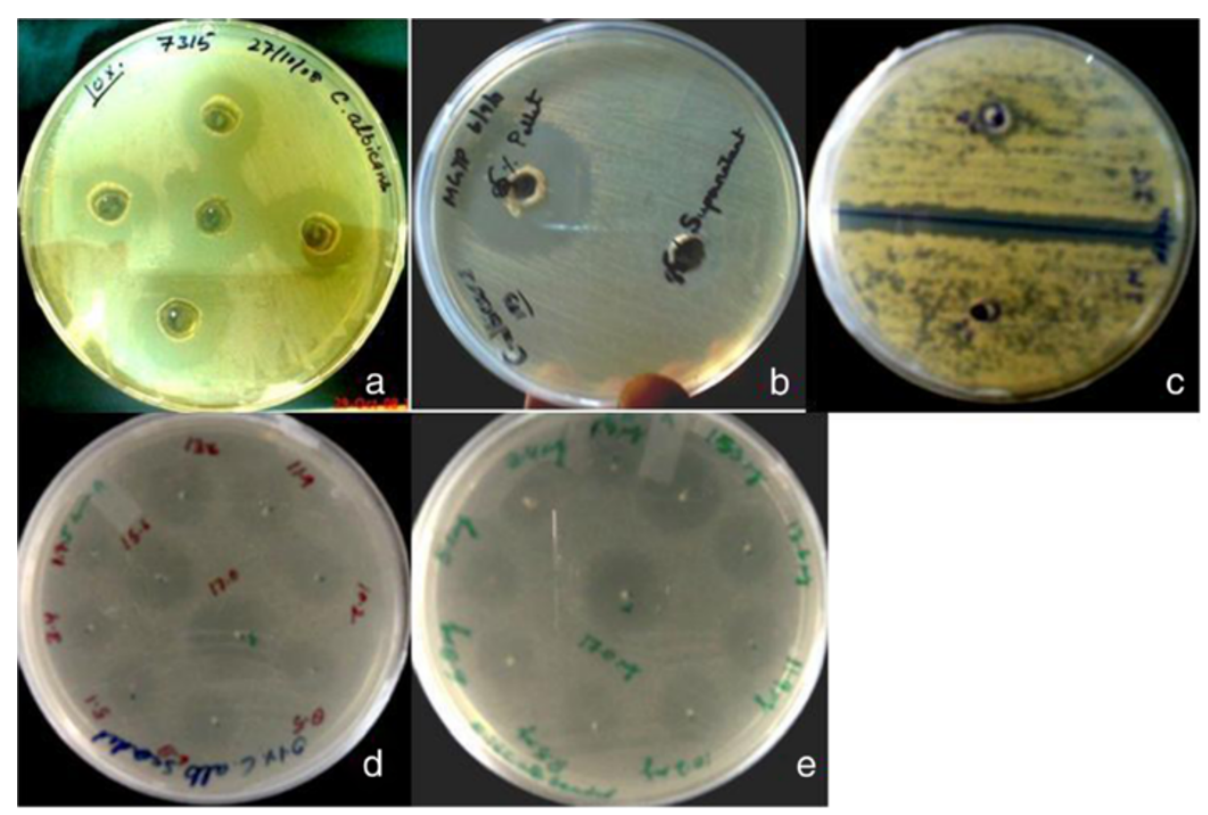

Figure 1 a. Biological activity of ACP against C. albicans (MTCC 7315). b. Biological activity of ACP against C. albicans (MTCC 183) after 85\% ammonium sulfate fractionation, The zone of inhibition was detected in 85\% palette dissolved in $20 \mathrm{mmol}$ sodium phosphate buffer pH 8.0, but activity was not detected in supernatant. c. Mild biological activity of ACP against wild type C. albicans (DI) isolated from a diabetic patient in BITS Goa. $\mathbf{d}$ and $\mathbf{e}$. Different concentration of dialyzed concentrate of ACP showing zone of inhibition against a lawn of C. albicans MTCC 183. 


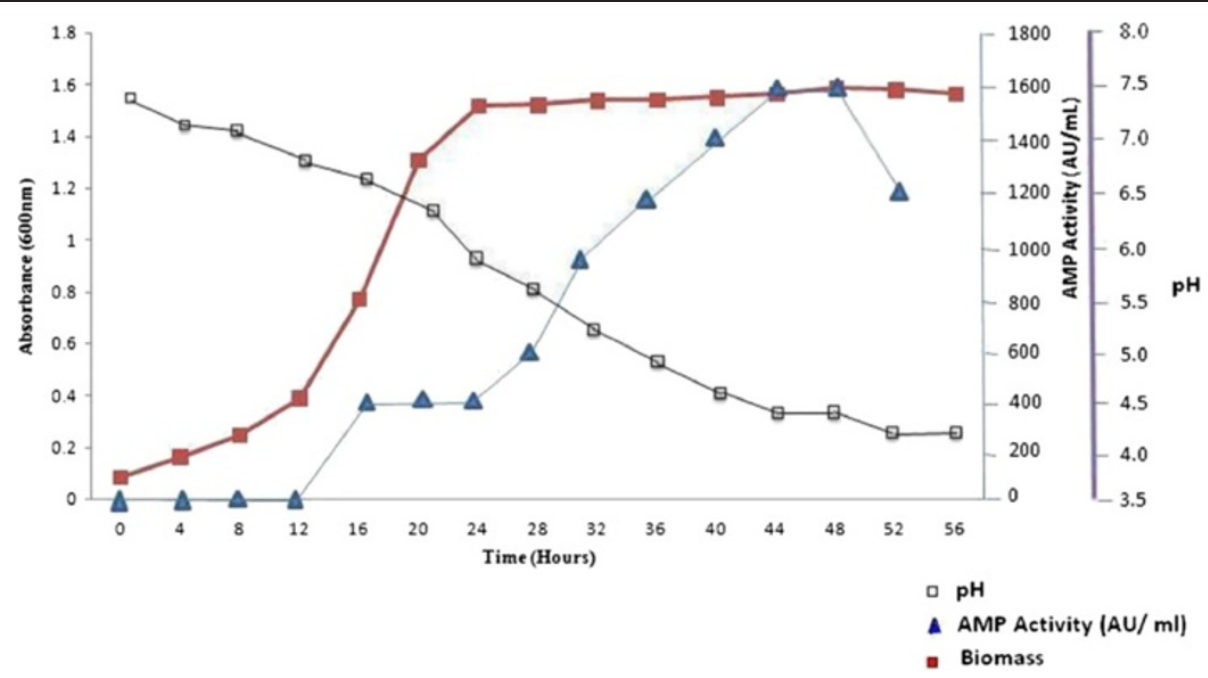

Figure 2 Kinetics of anti-mycotic protein and biomass production of $E$. faecalis.

\section{Purification of the anti-Candida compound}

The highest antifungal activity against different C. albicans strains was present mainly in the fraction precipitated with $85 \%$ ammonium sulfate (Figure 1b). Fractions precipitated with $30 \%$ and $50 \%$ ammonium sulfate exhibited weak inhibition. The supernatant obtained after $85 \%$ ammonium sulfate precipitation clearly did not exhibit any antifungal activity. The antifungal substance present in the $85 \%$ cut-off also inhibited germ tube formation in $C$ albicans NCIM 3471 (data not shown). As is clear from Table 3, ammonium sulfate precipitation resulted in an approximate 2 -fold increase in specific activity.
After ion- exchange chromatography using DEAE Sepharose, the adjacent fractions $31-35$ in the chromatogram, showed biological activity (Figure 3), and the specific activity increased 17-fold. After gel filtration, the recovery was approximately 22-fold. Based on the purification steps summarised in Table 3, it was concluded that the total active antimycotic protein recovered was $0.45 \%$ only.

\section{Direct detection of activity on PAGE}

After gel filtration, partially purified active pooled fractions $(30 \mu \mathrm{L})$, were loaded onto Tricine gel containing

Table 2 Effect of enzymes, heat, pH, organic solvents and surfactants on the biological activity of ACP (+ve sign, biological activity retained, -ve sign, loss of biological activity)

\begin{tabular}{|c|c|c|c|}
\hline Treatment $(w / v)$ & Activity & Treatment (v/v) & Activity \\
\hline Trypsin $\left(1.0 \mathrm{mg} \mathrm{ml}^{-1}\right)$ & + & Methanol (25\%) & + \\
\hline Pronase $\mathrm{E}\left(1.0 \mathrm{mg} \mathrm{m}^{-1}\right)$ & - & Ethanol (25\%) & + \\
\hline Proteinase $\mathrm{K}\left(1.0 \mathrm{mg} \mathrm{m}^{-1}\right)$ & - & Iso-propanol (10\%) & + \\
\hline Pepsin (1.0 mg ml-1) & + & Hexane (25\%) & + \\
\hline a-Amylase $\left(1.0 \mathrm{mg} \mathrm{m}^{-1}\right)$ & + & Formaldehyde (10\%) & + \\
\hline Lipase $\left(1.0 \mathrm{mg} \mathrm{ml}^{-1}\right)$ & + & Chloroform (10\%) & + \\
\hline Lysozyme (2.0 mg ml$\left.{ }^{-1}\right)$ & + & Acetone (10\%) & + \\
\hline $37^{\circ} \mathrm{C}, 60^{\circ} \mathrm{C}$ for $90 \mathrm{~min}$ & + & Acetonitrile (70\%) & + \\
\hline $90^{\circ} \mathrm{C}$ for $20 \mathrm{~min}$ & + & Triton X-100 (1\%v/v) & + \\
\hline $100^{\circ} \mathrm{C}$ for $30 \mathrm{~min}$ & - & Tween-20 (1\%v/v) & + \\
\hline $100^{\circ} \mathrm{C}$ for $90 \mathrm{~min}$ & - & SDS $(1 \% \mathrm{w} / \mathrm{v})$ & ++ \\
\hline $121^{\circ} \mathrm{C}$ for $15 \mathrm{~min}$ & - & Urea $(1 \% \mathrm{w} / \mathrm{v})$ & + \\
\hline Control at $4^{\circ} \mathrm{C}$ & + & EDTA $(1 \% w / v)$ & + \\
\hline$(\mathrm{pH}) 6.0,7.0$ and 8.0 & + & PMSF (1\%v/v) & + \\
\hline \multirow[t]{2}{*}{$(\mathrm{pH}) 2.0,4.0$ and 10.0} & - & $\beta$-Mercaptoethanol (1 mmol) & + \\
\hline & & DTT (0.1 mol) & + \\
\hline
\end{tabular}


Table 3 Summarised Purification steps of ACP

\begin{tabular}{|c|c|c|c|c|c|c|}
\hline Purification stage & $\begin{array}{l}\text { Volume } \\
(\mathrm{mL})\end{array}$ & $\begin{array}{l}\text { Activity } \\
\left(\text { AU mL }{ }^{-1}\right)\end{array}$ & $\begin{array}{l}\text { Protein } \\
\left(\mathrm{mg} \mathrm{mL}^{-1}\right)\end{array}$ & $\begin{array}{l}\text { Specific activity } \\
\text { (AUmg }^{-1} \text { protein) }\end{array}$ & $\begin{array}{l}\text { Purification } \\
\text { factor }\end{array}$ & $\begin{array}{l}\text { Recovery } \\
(\%)\end{array}$ \\
\hline Culture Supernatant & 400 & 1600 & 0.4025 & 39751 & 1 & 100 \\
\hline Ammonium sulfate and dialysis & 10 & 3200 & 0.0444 & 72072 & 1.8 & 11 \\
\hline Ion Exchange Chromatography & 6 & 1600 & 0.0023 & 695652 & 17.5 & 0.57 \\
\hline Gel Filtration & 2 & 1600 & 0.0018 & 888888 & 22.4 & 0.45 \\
\hline
\end{tabular}

$10 \%$ resolving and 5.0\% stacking gel. A clear zone of inhibition on the C. albicans MTCC 3958 overlaid gel was shown in a Petri dish (Figure 4), wherein a simultaneously silver stained gel showed a corresponding band that was responsible for the biological activity. Based on the polypeptide molecular weight marker, the molecular mass of the active peptide was estimated to be approximately $43 \mathrm{kDa}$ (Figure 4). We did not observe any biological activity of the bands using glycine Native PAGE.

\section{Amino acid sequencing}

The first 12 amino acid residues of the $\mathrm{N}$-terminal were determined by Edman degradation. The minor sequence obtained from the twice repeated $\mathrm{N}$-terminal sequencing was GPGGPG, and the same partial sequence was matched for homology. Complete homology was not found in the NCBI BLAST result. However, the GPGG sequence matched a known $\mathrm{ABC}$ transporter, i.e. $\mathrm{ABC}$ Transporter peptide permease and hypothetical protein. The first three amino acid residue GPG matched with $\mathrm{N}$-terminal sequence of enterocin 1071B [21,22]. Likewise the GPG sequence was also observed in EntC2 [23]. Analysis of the major N-terminal sequence DEVYTVKS
$\left(S+S^{\prime}\right)$ GLS revealed the presence of $S^{\prime}$ suggesting a modified serine which is a feature of class I lantibiotics. This sequence was almost similar to those found in autolysin and hypothetical protein of E. faecalis.

\section{Amino acid composition and sequence analysis done by de novo sequencing}

Based on the de novo sequence the combined peptides having 40 amino acid residues were assembled. Individual peptides having $\mathrm{m} / \mathrm{z}$ 718, 1039 and 601 were found. The combined peptide did not contain any charged acidic residues (Asp, Glu). Hydrophobic amino acids constituted (42.5\%, excluding Gly). The peptides did not significantly match any known proteins present in the MASCOT and BLASTp databases. The amino acid sequence of ACP (40 residues) obtained from peptide fragments after digestion of the antimycotic protein with trypsin was analyzed by MS/MS spectra using PEAKS Studio Version 4.5 SP2 [Bioinformatics Solutions] with subsequent de-novo sequencing. The peaks obtained are indicated in the sequence below, and overlapping residues are shown in bold. The de novo spectra for peptides are given in Figure 5a, b, and c.

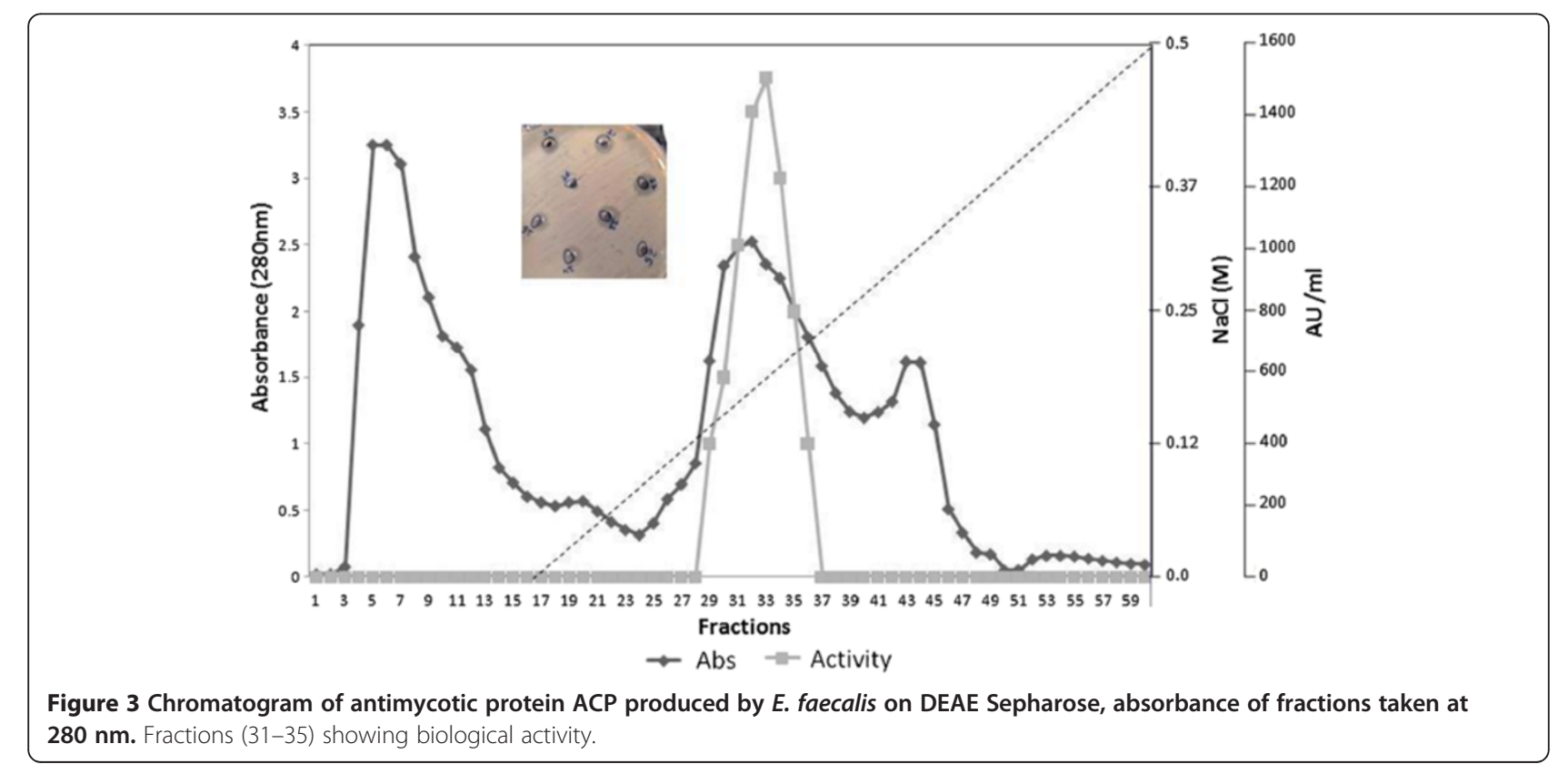




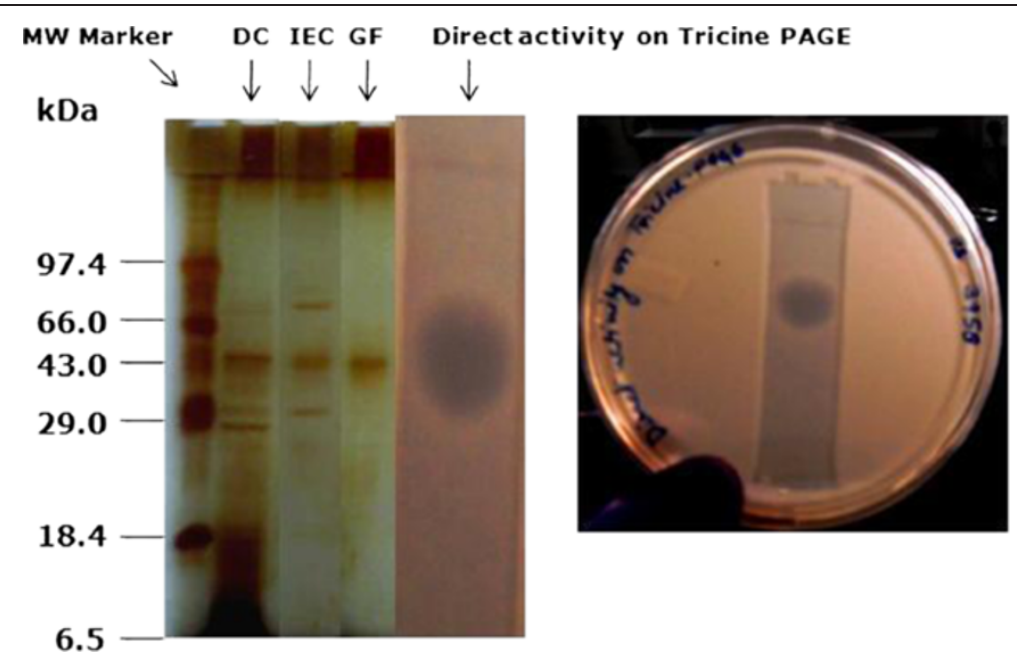

Figure 4 Tricine-PAGE of ACP purification fractions and gel overlay with C. albicans (MTCC 183). Lane 1, molecular weight marker. Lane 2, dialyzed concentrate after $85 \%$ ammonium sulfate fractionation. Lane 3, pooled active fractions collected through DEAE Sepharose matrix. Lane 4, silver stained fractions after gel filtration using Sephadex-G 75. Lane 5, Inhibition zone by antimycotic protein (ACP) on the overlay gel.

Unfiltered BLAST searches using the de novo sequences did not identify any sequence with homology in the Protein Data Bank (PDB). Only a small patch of sequence matched; for example, a WL motif that was found 2 times in enterocin 1071B amino acid sequence [23], and was found 4 times in WLPPAGLLGRCGRWFRPWLLWLQS GAQYKWLGNLFGLPGK in the combined novo sequence (Figure 5d) of ACP. Earlier study on Ponericin W1 and W2 revealed WL and GL motifs and the presence of hydrophobic residues.

\section{MIC of the dialysed concentrate containing ACP}

The highest minimal inhibitory concentration (MIC), $1067 \mu \mathrm{g} \mathrm{mL} \mathrm{g}^{-1}$ of dialysed concentrate containing ACP was found against wild type $C$. albicans (DI) whereas the lowest MIC, $133 \mu \mathrm{g} \mathrm{mL}^{-1}$ was found against MTCC 183 and MTCC 7315.The MIC of ACP against MTCC 3958 was $267 \mu \mathrm{g} \mathrm{mL}^{-1}$ (Figure 6).

\section{Haemolytic and haemagglutination activity assays}

Freshly grown $E$. faecalis, streaked on sheep blood agar plates, did not produce a clear haemolytic zone whereas a clear transparent zone was produced by Streptococcus pyogenes and $S$. aureus used as controls. The cytotoxic effect of the extracellular proteins of $E$. faecalis against human RBCs was determined by haemolytic and haemagglutination assays. The effect of various concentrations of the purified anti-Candida compound on human erythrocytes is reported in Figure 7. The ACP showed negligible haemolytic activity up to the concentration of $0.4 \mathrm{mg} \mathrm{mL}^{-1}$ whereas a very weak haemolytic activity of $3.76 \%$ at the concentration of $6.4 \mathrm{mg} \mathrm{mL}^{-1}$ of antiCandida protein was found.
No haemagglutination activity of ACP was found up to1.6 $\mathrm{mg} \mathrm{mL}^{-1}$; however, a slight haemagglutination activity was observed at $3.2 \mathrm{mgmL}^{-1}$ concentration (Figure 8).

\section{Discussion}

Biochemical characteristics and fatty acid methyl ester (FAME) analysis identified the strain as E. feacalis, whereas $16 \mathrm{~S}$ rDNA sequencing identified the strain as $E$. faecium [19]. Potassium tellurite reduction, however, distinguished the strain as E. faecalis rather than E. faecium. The concentrate made from the CFS of the test strain inhibited 7 multidrug resistant strains of $C$. albicans.

There are several bacteriocins from E. faecalis and other species origin $[15,24]$, but antimycotic peptides or proteins are rare. Pseudomonas syringie and some Bacillus species produce antifungal peptides, but no such reports about $E$. faecalis [25] were found. The genus Enterococcus belongs to a group of important lactic acid bacteria (LAB) that participate and contribute towards different fermentation processes. Their functionality in dairy and meat products has been reported in detail $[26,27]$. Several bacteriocins produced by Enterococcus species [24] or other enterococci of different origins [15], have been reported and characterized at the biochemical and genetic levels. Several antifungal peptides (iturins, bacillomycins) were discovered from Bacillus and Pseudomonas. Nikkomycins, produced by Streptomyces tendae and S. ansochromogenes, and polyoxins, produced by S. cacaoi, are the most widely studied antifungal peptides, whereas antifungal peptides from Enterococcus species [25,28] are rare. Various strains of Bacillus subtilis produce iturin A and bacillomycin L peptide. Iturins inhibited the growth of fungi including Aspergillus niger, C. albicans, and F. oxysporum [29,30]. 
Shekh and Roy BMC Microbiology 2012, 12:132

Page 7 of 15

http://www.biomedcentral.com/1471-2180/12/132

a. De novo spectra for peptide $718.29 \mathrm{~m} / \mathrm{z}$, WLPPAGLLGRCGR

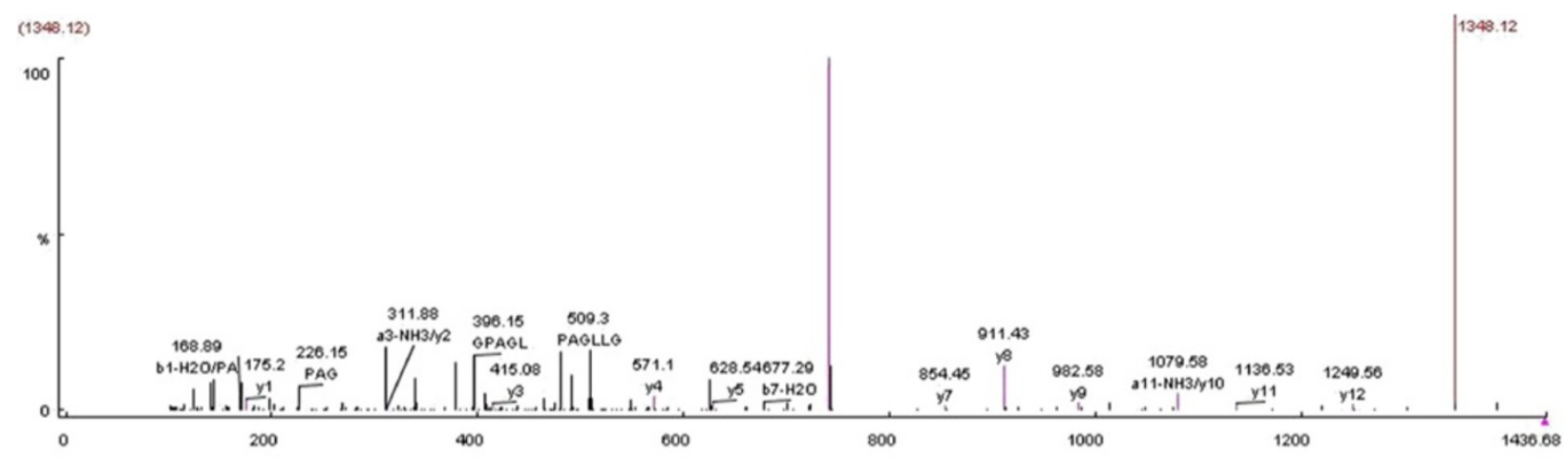

b. De novo spectra for peptide 1,039.72 m/z, WFRPWLLWLQSGAQYK

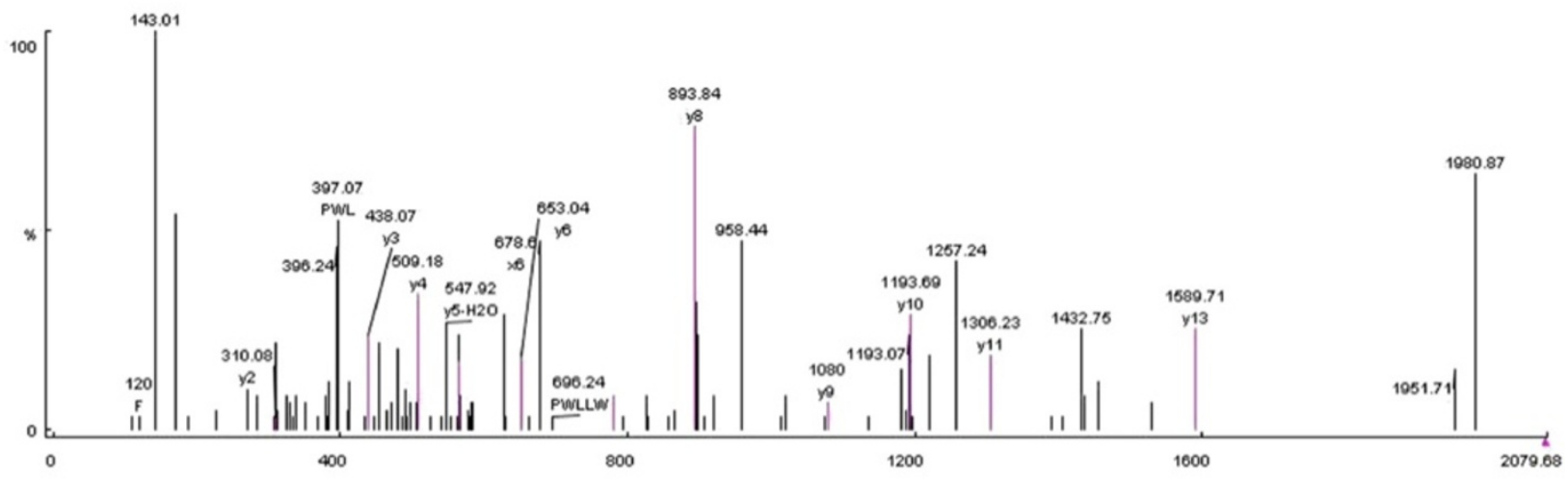

c. De novo spectra for peptide $601.24 \mathrm{~m} / \mathrm{z}$, WLGNLFGLPGK

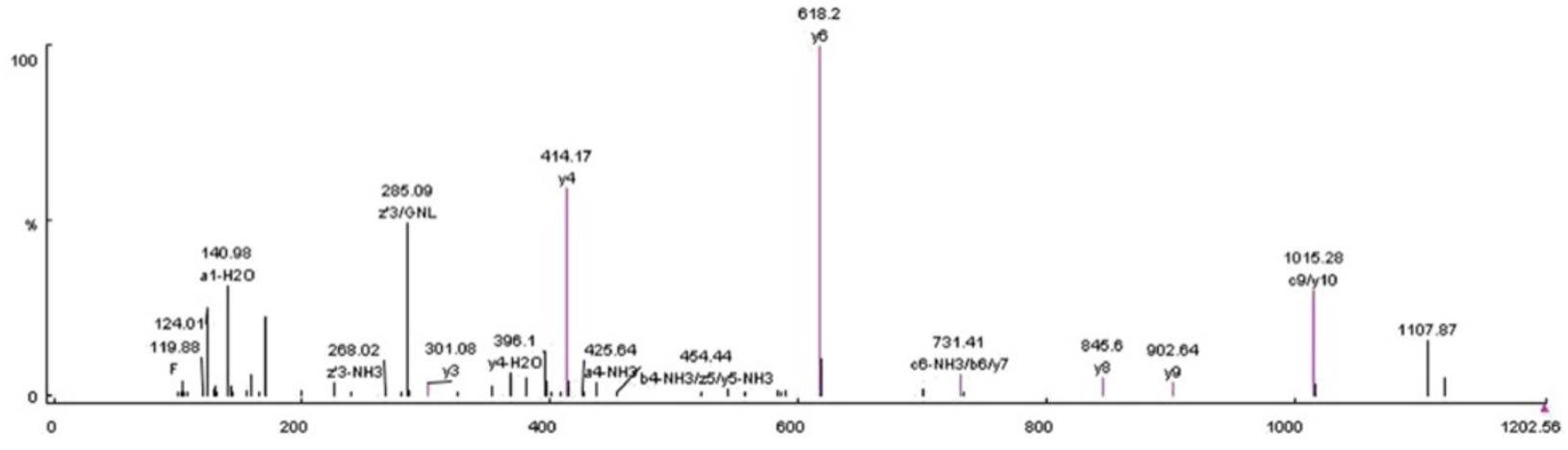

d.

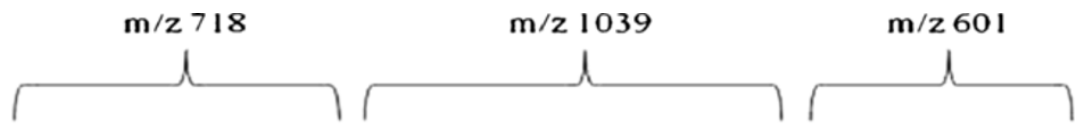

WLPPAGLLGRCGRWFRPWLLWLQSGAQYKWLGNLFGLPGK

Figure 5 a. De novo spectra for peptide 718.29 m/z, WLPPAGLLGRCGR. b. De novo spectra for peptide 1,039.72 m/z, WFRPWLLWLQSGAQYK. c. De novo spectra for peptide 601.24 m/z, WLGNLFGLPGK. d. Combined de novo sequence of ACP having 3 peptide residues of $\mathrm{m} / \mathrm{z}$ ratio 718 , 1039 and 601. 


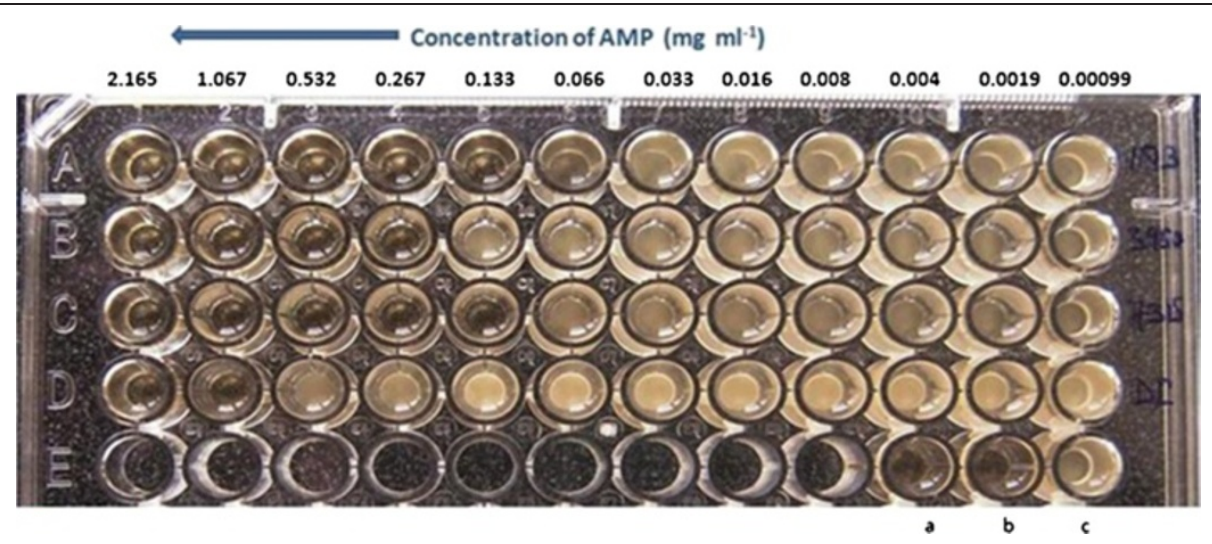

Figure 6 Antimycotic effect of ACP on the growth of C. albicans (MTCC 183, 3958, 7315, and DI), analyzed by a microbroth dilution assay. Well (a) medium only, well (b) ACP in the medium only, well (c) Grown C. albicans in the medium. Rows A-D, normal growth of Candida albicans, wells treated with different concentrations of ACP.

Initial clinical trials involving humans and animals showed that iturin A was effective against dermatomycoses and had a wide spectrum of antifungal properties and low allergenic effects [31]. Unfortunately, bacillomycin L and iturin A are haemolytic, which may reduce their potential use as antifungal drugs [32].

In an era of increased incidence of fungal infections in immunocompromised patients $[33,34]$ and greater resistance to 'frontline' antifungal therapies [35], there is a growing need to discover new antifungal therapies. Although newer azole derivatives such as voriconazole are more effective and have cidal activity against filamentous fungi such Aspergillus fumigatus [36], these derivatives are fungistatic and not fungicidal against pathogenic yeasts. The inability to kill yeasts leads to resistance to azole in prolonged infections and increases the likelihood that these agents will lack efficacy in severe Candida infections in immunosuppressed patients. Amphotericin B has also been commonly used to treat serious fungal infections, but in contrast to azoles, amphotericin B is fungicidal against yeasts. Nevertheless, resistance to amphotericin B is slowly developing in selected Candida species [37] and there are significant side effects associated with its use, including nephrotoxicity. Although recently developed antifungal agents, including the peptide-based agents' micafungin and caspofungin, are very promising, resistance to these therapies has already been reported [38-40] and will no doubt become more widespread. The development of resistance to current antifungal agents, the limited efficacy, and the side effects associated with several of these agents increase the importance of continued development of new alternative approaches.

The identified Enterococcus faecalis strain produces the antimycotic substance, ACP, extracellularly. The activity of the ACP was stable upon treatment at different temperatures, for up to $90^{\circ} \mathrm{C}$ for $20 \mathrm{~min}$ but the activity was lost after boiling and autoclaving. While similar results have been reported for bacillomycin $\mathrm{D}$ from $B$. subtilis [41] and durancin L28-1A from $E$. durans [42], bacteriocin ST15 from E. faecium was inactivated when subjected to $121^{\circ} \mathrm{C}$ for $20 \mathrm{~min}$ [43]. The antimycotic property of the ACP also remained unaffected in the $\mathrm{pH}$ range of 6.0-8.0. At $\mathrm{pH}$ values of 5.0 and 9.0, however, the activity was reduced by $50 \%$ whereas at values of $\mathrm{pH} 2.0$, 4.0 , and 10.0 activity was lost completely. These results are similar to those reported for the bacteriocin produced by E. mundtii [44]. Several bacteriocins produced by enterococci are known to exhibit a wide range of $\mathrm{pH}$ stability [45]. The ACP was stable in different organic solvents and surfactants; such stability has been a common feature of many

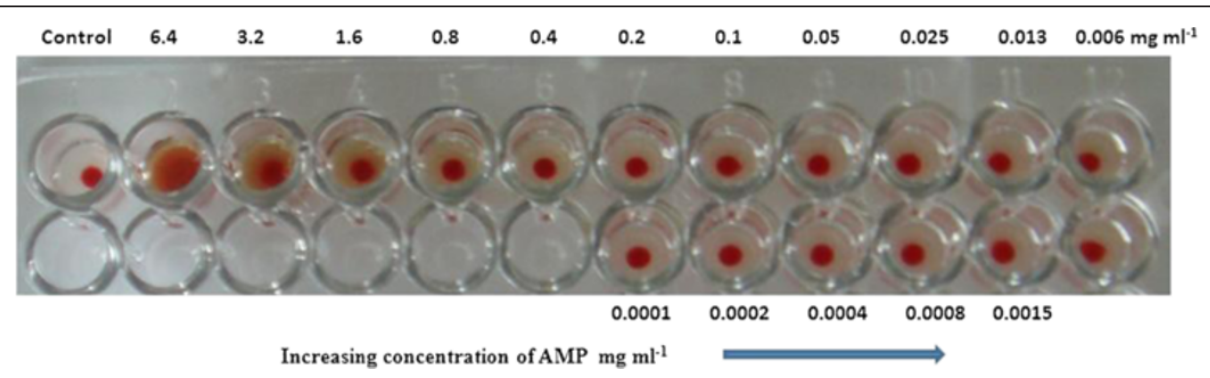

Figure 7 Haemolytic activity of the dialyzed concentrate containing ACP against human erythrocyte cells. 


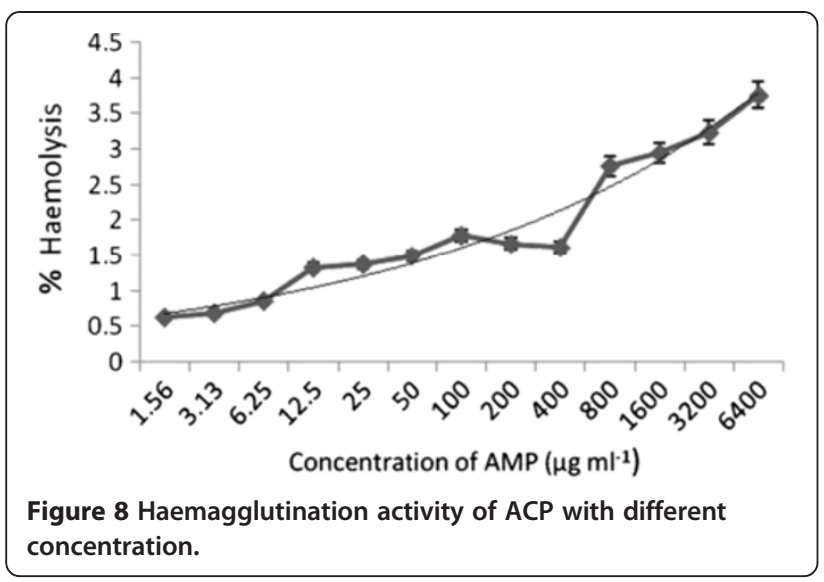

bacteriocins produced by Enterococcus, AMP produced by Bacillus species, and other LAB [43,46,47].

The ACP was fully sensitive to proteinase $\mathrm{K}$ and partially sensitive to pronase $\mathrm{E}$, confirming its proteinaceous nature. Its resistance to pepsin, lysozyme and trypsin indicated that the anti-Candida active principle may be a cyclic peptide containing unusual amino acids and therefore more resistant to protease hydrolysis [48]. These results suggested that this antimycotic peptide could survive in the intestinal environment and might therefore be administered with food [49]. On the other hand, the ineffectiveness of $\alpha$-amylase and lipase on antimycotic activity suggested that the ACP might not be glycosylated and might not contain a lipid moiety. When the ACP was heated with $1 \mathrm{mmol}$ and $2 \mathrm{mmol} \beta$-mercaptoethaol at $80^{\circ} \mathrm{C}$ for $10 \mathrm{~min}$ to ensure thiol residues existed in the reduced state, no particular change in antimycotic activity was observed. This indicates that the oxidation state of the cysteine residues may not be important for the antimycotic activity [50]. When the dialysed ACP was treated with the reducing agent DTT, no decrease in inhibitory activity was observed, indicating that disulphide bonds are not responsible for biological activity. It was also observed that storage of $\mathrm{ACP}$ at $-80^{\circ} \mathrm{C}$ for 1 year did not significantly affect biological activity. Ammonium sulfate salt as well as sodium phosphate buffer did not inhibit ACP activity at the concentration used and did not modify the result of the assay. The dialysed concentrate of ACP, dissolved in $20 \mathrm{mmol}$ sodium phosphate buffer, weakly bound with the DEAE Sepharose matrix, indicating that the ACP bears negative charges. Being weakly negative, it was separated easily in native polyacrylamide gel electrophoresis. After purification by ammonium sulfate fractionation, dialysis, anion exchange chromatography and gel filtration, the final amount of recovered protein $(0.45 \%)$ was found very low. This could be increased by using protein engineering and optimization methods.

Comparing the partial amino acid sequence of the purified antimycotic protein to other antimicrobial peptides and bacteriocins by using protein-protein BLAST in NCBI revealed no complete homology with other known bacteriocins or AMPs. The combined N-terminal and de novo sequence GPGGPG...WLPPAGLLGRCGRWFRPWLLW LQSGAQYKWLGNLFGLGPK had high amounts of glycine, proline, leucine and tryptophan. This has been observed in many antimicrobial peptides including bacteriocins like enterocin and acidocin.

It was reported earlier that the glycine-rich antifungal peptide tenacin-3 enters the C. albicans cytoplasm [51], although tenacin-3 seems not to induce membrane permeabilisation. Linear peptides with an extended structure were characterised by an unusual proportion of one or more amino acids (most often proline, tryptophan, or glycine) $[52,53]$. Penaedins characterised from shrimps and prawns had a high content of Pro/Arg/Gly residues in the extended N-terminal domain [54]. Oxypinin 2 has a GVG motif, and ponericin $G$ has glycine residues flanking the central proline, resulting in a GPG motif with calculated grand average of hydropathicity (GRAVY) of -0.683 .20 . The presence of Gly-Pro hinges in antimicrobial peptides like oxypinins, ponericins, and cecropins supports the antimicrobial potential of $\mathrm{ACP}$, wherein a similar sequence was observed. The regional flexibility provided by proline was sometimes enhanced by the presence of glycine residues [55]. In another recent report, a penaedin homologue, hyastatin from spider crab [56], was shown to possess a Pro/Gly domain similar to the N-terminal domain of penaedins that bind chitin tightly. This information strengthens the idea that the $\mathrm{N}$-terminal minor sequence GPGGPG of the anti-Candida protein in the present study could interact with the cell wall of Candida as a primer for antimicrobial action [56]. In such a proline-rich sequence, a proline kink has all the potential to create pores [57]. It was cogently argued that in cationic hydrophobic peptides the presence of polar residues confers a hydrophilic property to the proline-rich peptides. In an earlier study conducted on curvaticin FS47, the neutral (Gly [24\%]) and hydrophobic (Ala, Ile, Leu, Val, Pro, and Phe [47\%]) residues at the N-terminal constitute a significant proportion which helps to explain the hydrophobic interactions that curvaticin FS47 displays. It was reasoned that the high proportion of Gly residues (23.9\% in ACP) would likely provide a significant amount of flexibility to the antimicrobial molecule [58]. In fact, the increase of hydrophobicity of the peptides also correlated with fungicidal activity [59]. In accordance with many other bacteriocins of LAB e.g., lactococcin A [60], lactacin F [61], and curvaticin FS47 [58], a high proportion of glycine was likely to provide a significant amount of flexibility to the molecule. A recent study on lactococcin G, enterocin $1071 \mathrm{~B}$, and EntC2 suggested that the $\mathrm{N}$-terminal sequence of the peptide of each bacteriocin ( $\operatorname{LcnG} \beta$, Ent1071B and EntC2) is important for determining target cell specificity $[23,62]$. 
Previously, the $\mathrm{N}$ - terminal sequence of the antimicrobial dermaseptin B was reported to be highly hydrophobic which could enable its binding to zwitterionic outer and negatively charged surfaces [63]. In addition, the part of the N-terminal sequence which contains Gly-Pro residues and the combined de novo sequence detected in the anti-Candida protein ACP 43 under current investigation, were supported by the inference that proline-rich peptides (often associated with arginine) enter cells without membrane lysis and after entering the cytoplasm bind to and inhibit the activity of specific molecular targets causing cell death [64]. Other studies with model amphipathic all L- amino acid peptides with the sequence KX3KWX2KX2K, where X=Gly, Ala, Val, or Leu showed that the leucine-rich peptide, rather than the Ile- or Val-containing peptide, was particularly antimicrobial [63]. Our result is in agreement with this observation: leucine amounted to $19.6 \%$, and proline (13.0\%) was in association with arginine.

The combined sequence derived from the de novo sequencing, WLPPAGLLGRCGRWFRPWLLWLQ SGAQY KWLGNLFGLGPK, showed high content of glycine (17.5\%), proline, leucine and tryptophan. The amino acid content also revealed that the peptide was quite hydrophobic due to the presence of high amounts of leucine (22.5\%), and this is believed to play a role in the interactions with the cell membrane [61]. The hydrophobicities (GRAVY) of individual peptides having $\mathrm{m} / \mathrm{z} 718,1039$ and 601 were $0.108,-0.388$ and 0.282 respectively, which indicates that these peptides are relatively hydrophobic and characteristic of many bacteriocins isolated from $E n-$ terococcus species [65]. High levels of glycine (31\%) and glutamine $(18 \%)$ residues in another cationic antifungal peptide constitutively produced by $S$. peregrine larva were also reported to bind $C$. albicans through electrostatic interaction and disturb the osmotic integrity of treated cells [56]. In contrast, a novel glycine/leucinerich antimicrobial peptide, leptoglycine (glycine 59.1\% and leucine $36.4 \%$ ) derived from Leptodactylus pentadactylus failed to inhibit $C$. albicans. We have used the combined de novo sequence to predict the structure using the PSIPRED (Protein Structure Prediction) server. The sequence WFRPWLLWLQSGAQYK showed alpha helical structure, which is characteristic of many antimicrobial peptides [63].

The MIC of the ACP against wild-type C. albicans DI was $1067 \mu \mathrm{g} \mathrm{ml}^{-1}$, whereas the lowest MIC, $133 \mu \mathrm{g} \mathrm{mL}{ }^{-1}$, recorded was against MTCC 183 and MTCC 7315.The MIC of the ACP against MTCC 3958 was $267 \mu \mathrm{g} \mathrm{mL}{ }^{-1}$ which was slightly higher than the MICs of iturin and bafilomycin F [25]. In this study, the results of toxicity experiments were of great interest. ACP was non-toxic to human erythrocytes up to a tested concentration of $6.4 \mathrm{mg} \mathrm{mL} \mathrm{m}^{-1}$. At this concentration, the percent haemolytic activity was 3.76 which is comparatively much less than the haemolytic activities of baciamin [66] and bafilomycin F [25].

It was also concluded that ACP was not able to hemagglutinate human red blood cells up to the concentration of $1.6 \mathrm{mg} \mathrm{ml}^{-1}$ (Figure 8), however the concentration higher than this were able to hemagglutinate the human $\mathrm{RBC}$, whereas this concentration is much more than the MIC of the ACP. These properties taken together might render this antimycotic protein ACP, a potent candidate for treating candidiasis, and its related pharmaceutical application can be established in synergy with other relevant antifungal antibiotics of low dosage.

\section{Conclusions}

In this study an antimycotic protein, ACP from the bacterial strain E. faecalis was purified to near homogeneity. This antimycotic peptide has negligible haemagglutination and haemolytic activity and hence potentially warrants use in synergy with low dosages of available antifungal drugs to inhibit multidrug resistant C. albicans.

\section{Methods}

\section{Bacterial strains, growth conditions, and media}

E. faecium (accession number HM481246) was routinely propagated in TGYE medium (tryptone, $5.0 \mathrm{gL}^{-1}$; glucose, $1.0 \mathrm{gL}^{-1}$; yeast extract, $3.0 \mathrm{gL}^{-1}$; $\mathrm{pH}$ 7.2-7.4). For ACP production, the strain was grown in optimized mTSB medium (glucose, $2.5 \mathrm{gL}^{-1}$; yeast extract, $2.5 \mathrm{gL}^{-1}$; pancreatic digest of casein, $17.0 \mathrm{gL}^{-1}$; papaic digest of soyabean meal, $3.0 \mathrm{gL}^{-1}$; sodium chloride, $5.0 \mathrm{gL}^{-1}$; $\mathrm{K}_{2} \mathrm{HPO}_{4}, 2.5 \mathrm{gL}^{-1}$; and $\mathrm{pH}$ 7.2). The indicator organism C. albicans used in biological activity (cut-well agar) assay was propagated in MGYP (malt extract, $3.0 \mathrm{gL}^{-1}$; glucose, $10 \mathrm{gL}^{-1}$; yeast extract, $3 \mathrm{gL}^{-1}$; peptone, $5.0 \mathrm{gL}^{-1}$, $\mathrm{pH}$ 6.4-6.8). The strain was grown in a BOD incubator maintained at $14^{\circ} \mathrm{C}$. All microbiological media components were purchased from Hi-Media, Mumbai, India.

Different strains of C. albicans were purchased from the Institute of Microbial Type Culture Collection (IMTECH), Chandigarh and National Collection of Industrial Microorganism (NCIM), Pune India. These yeast strains were subcultured regularly in MGYP agar and broth. In the current investigation, the wild-type clinical isolates DI and WI were also used. For their species identification, the fungal genomic DNA was extracted using the kit RTK13. For sequencing the amplicon, ABI 3130 genetic analyser (Chromous Biotech Pvt. Ltd. India) was used.

The test strain was subjected to carbohydrate fermentation using the Hi-Carbo kit KB009-20KT. All strains were stored in appropriate media with $20 \%$ glycerol at $-80^{\circ} \mathrm{C}$. 


\section{Determination of the anti-Candida activity}

The anti-Candida activity was assayed against yeast C. albicans MTCC 183, MTCC 3958, MTCC 7315 and NCIM 3471 using the agar-well diffusion assay method as described previously [19]. To determine the titre of the antifungal activity, serial 2-fold dilutions of the extracts were performed. The anti-Candida activity was expressed as units $\mathrm{AU} \mathrm{mL}^{-1}$ corresponding to the reciprocal of the highest dilution causing inhibition of the yeast growth.

\section{Kinetics determination of $E$. faecalis}

The kinetics of antimycotic protein production was

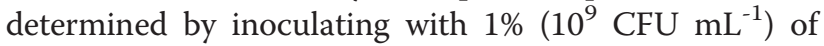
an overnight culture of $E$. faecalis in mTSB enriched broth and incubating at $14^{\circ} \mathrm{C}$ under uncontrolled $\mathrm{pH}$ conditions without agitation. At 4 hours interval, samples were collected to determine the optical density at $600 \mathrm{~nm}$ as well as $\mathrm{pH}$. The antimicrobial activity was determined assaying serial two fold dilutions of cell free culture supernatants against C. albicans MTCC 183

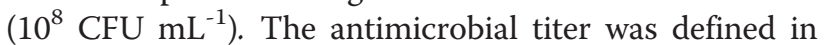
arbitrary units $\left(\mathrm{AU} \mathrm{mL} \mathrm{m}^{-1}\right)$ as the reciprocal of the highest dilution showing inhibition around the well $(5.0 \mathrm{~mm})$.

\section{Preparation of cell wall and cytoplasmic extract Sphaeroplast preparation}

E. faecalis $(4.0 \% \mathrm{v} / \mathrm{v})$ of was grown in $10 \mathrm{ml} \mathrm{mTSB}$ broth at $14^{\circ} \mathrm{C}$ until the OD at $600 \mathrm{~nm}$ was 0.5 . The cells were harvested by centrifugation at $10,000 \mathrm{rpm}$ for $10 \mathrm{~min}$ at $4^{\circ} \mathrm{C}$. The pellet was resuspended at $1 / 10^{\text {th }}$ the original volume in STE buffer $(6.7 \% \mathrm{w} / \mathrm{v}$ sucrose, $50 \mathrm{mmol}$ Tris- $\mathrm{HCl} 1 \mathrm{mmol}$ EDTA [pH 8.0]) containing $1 \mathrm{mg} \mathrm{mL}^{-1}$ lysozyme [67].

The mixture was incubated at $37^{\circ} \mathrm{C}$ for $30 \mathrm{~min}$ and was centrifuged at 5, $00 \mathrm{rpm}$ for $20 \mathrm{~min}$. The supernatant was collected and stored at $-80^{\circ} \mathrm{C}$ until use; the pellet (sphaeroplast) was used to prepare the cytoplasmic extract. The antimicrobial activity of the supernatant was tested against C. albicans MTCC 3958, C. albicans MTCC 183, P. aeruginosa MTCC 741 and Staphylococcus aureus MTCC 737.

\section{Extraction of cytoplasmic protein}

The sphaeroplast obtained was resuspended in hypotonic buffer (50 mmol Tris- $\mathrm{HCl}, \mathrm{pH}-7,1 \mathrm{mmol} \mathrm{MgCl}_{2}$, 25 U RNase A, 50 U DNase 1, [GeneI, India]) [68]. The mixture was incubated on ice for $30 \mathrm{~min}$. Then it was centrifuged at $12,000 \mathrm{rpm}$ for $30 \mathrm{~min}$ at $4^{\circ} \mathrm{C}$. The supernatant was collected and stored at $-80^{\circ} \mathrm{C}$ until use. The Antimicrobial activity of the supernatant was tested against C. albicans MTCC 3958, P. aeruginosa MTCC 741, S. aureus MTCC 737.

\section{Physicochemical properties of the anti-Candida compound}

Sensitivity to heat, $\mathrm{pH}$, and hydrolyzing enzymes

Temperature stability was evaluated by incubating the CFS at various temperatures: $60^{\circ} \mathrm{C}$ for $90 \mathrm{~min}, 90^{\circ} \mathrm{C}$ for $20 \mathrm{~min}, 100^{\circ} \mathrm{C}$ for 20 and $30 \mathrm{~min}$ or autoclaved. Residual anti-Candida activity was determined by a well-diffusion assay against $C$. albicans. The effect of $\mathrm{pH}$ was determined using a $\mathrm{pH}$ range from 2 to 10 adjusted with diluted $\mathrm{HCl}$ or $\mathrm{NaOH}$. After incubation at $37^{\circ} \mathrm{C}$ for $1 \mathrm{~h}$, the resulting CFS was subjected to an agar-well diffusion assay to record the loss or retention of biological activity. Resistance to several proteolytic enzymes was tested by incubating the dialysed concentrate with pepsin, $\alpha$-amylase, pronase $\mathrm{E}$, trypsin, lipase and proteinase $\mathrm{K}$ at a final concentration of $1.0 \mathrm{mg} \mathrm{mL}^{-1}$. Buffers were used as controls. Samples were incubated at $37^{\circ} \mathrm{C}$ for $90 \mathrm{~min}$. The residual activity was determined by cut-well agar assay.

\section{Effect of organic solvents, surfactants, and storage}

The sensitivity of dialyzed concentrate of ACP was tested in the presence of several organic solvents (methanol, ethanol, isopropanol, hexane, formaldehyde, chloroform, acetone and acetonitrile) at a final concentration of $25 \%(\mathrm{v} / \mathrm{v})$. After incubation for $2 \mathrm{~h}$ at $37^{\circ} \mathrm{C}$, the organic solvent was evaporated using a speed vac system (Martin Christ), and the residual antimicrobial activity was determined. An untreated dialysed concentrate sample was taken as control. The effect of various surfactants, including Triton X-100, Tween-20, SDS, urea, EDTA, PMSF, and DTT (1.0\% each) on the dialyzed concentrate was also tested. To assess whether the antifungal activity was due to the oxidation state of cysteine residues, $\beta$-mercaptoethanol ( 1 and $2 \mathrm{mmol}$ ) was used. The heat-treatment at $80^{\circ} \mathrm{C}$ was given for $10 \mathrm{~min}$.

In order to determine the stability, the CFS, dialyzed concentrate and partially purified ACP samples were stored for 1 year at low temperatures $\left(4,-20\right.$ and $\left.-80^{\circ} \mathrm{C}\right)$ and the antimicrobial activity was compared to the freshly purified preparation.

\section{Partial purification of the anti-Candida compounds}

E. faecalis was cultured in mTSB medium at $14^{\circ} \mathrm{C}$ for $48 \mathrm{~h}$. Cells were harvested by centrifugation at $12,000 \mathrm{rpm}$ for $30 \mathrm{~min}$ at $4^{\circ} \mathrm{C}$, and the CFS was filtered through $0.45 \mu \mathrm{m}$ membranes. The culture supernatant was subjected to sequential ammonium sulphate precipitation to achieve $30 \%, 50 \%$ and $85 \%$ saturation at $4{ }^{\circ} \mathrm{C}$ with constant and gentle stirring for $1 \mathrm{~h}$. The precipitated proteins were pelleted by centrifugation at $12,000 \mathrm{rpm}$ for $30 \mathrm{~min}$. The protein pellet was dissolved in sterile $20 \mathrm{mmol}$ sodium phosphate buffer $\mathrm{pH} 8.0$, and dialysed using a $10 \mathrm{kDa}$ MWCO membrane (Slide-ALyzer Dialysis Cassette, Thermo Scientific) overnight at 
$4^{\circ} \mathrm{C}$, against the same buffer. The crude preparation was then stored at $-80^{\circ} \mathrm{C}$ for further analysis. The $10 \mathrm{~mL}$ DEAE Sepharose column $(12 \mathrm{~cm}$ length and $1.5 \mathrm{~cm}$ diameter) was packed. The packed column was equilibrated with $20 \mathrm{mmol}$ sodium phosphate buffer, and $5 \mathrm{~mL}$ of dialyzed concentrate was loaded on top of the column. A linear gradient of 0 to $0.25 \mathrm{M} \mathrm{NaCl}$, including 20 mmol sodium phosphate buffer, $\mathrm{pH}$ 8, was applied. As many as 60 fractions of $3 \mathrm{~mL}$ were collected, and all the fractions were tested for anti-Candida activity using the agar-well diffusion assay. The absorbances of all fractions were recorded at $280 \mathrm{~nm}$. All the fractions with antifungal activity were pooled and subjected to ultra filtration (Pall Science) for concentration and removal of salts. Gel filtration chromatography of the pooled active sample was also performed with a Sephadex G 75 column $(1.0 / 45 \mathrm{~cm})$ for final polishing of active protein. The column was eluted isocratically with $20 \mathrm{mmol}$ sodium phosphate buffer, $\mathrm{pH} 8.0$, at a flow rate of $40 \mathrm{~mL} \mathrm{~h}^{-1}$. All the peaks were collected as separate fractions, concentrated by ultra filtration, and tested for antifungal activity using the cut well agar diffusion assay. The absorbance was monitored at $280 \mathrm{~nm}$.

\section{Direct detection of antifungal activity on gel}

Tricine Native-PAGE (10\%) [69], followed by a gel overlay was performed with active pooled fractions from gel filtration. After electrophoresis for $2 \mathrm{~h}$ at $20 \mathrm{~mA}$, when the dyefront reached at the bottom, 2 duplicate gels were cut. One of the gels was silver stained (based on the Alphalyze protocol). The other gel was fixed in $20 \%$ $(\mathrm{v} / \mathrm{v})$ isopropanol and 10\% (v/v) acetic acid for $30 \mathrm{~min}$, with $500 \mathrm{~mL}$ of MilliQ water for $1 \mathrm{~h}$, and placed aseptically on an MGYP plate. To identify the active peptide band, the tricine gel containing pooled active fraction was overlaid by freshly grown C. albicans MTCC 3958. After the agar solidified, the plate was incubated at $37^{\circ} \mathrm{C}$ for 48-72 h until C. albicans grew uniformly over the plate or an inhibition zone was observed.

\section{Determination of minimal inhibitory concentration (MIC)}

The MIC of the dialyzed concentrate against C. albicans (MTCC 183, MTCC 3958, MTCC 7315, and wild type C. albicans DI from Goa) was determined by the microbroth dilution assay in a 96-well microtitre plate

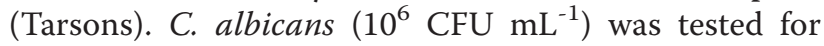
sensitivity to 2 -fold increasing dilutions of the compounds (2.165 to $\left.0.00099 \mathrm{mg} \mathrm{mL}^{-1}\right)$. After incubation at $37^{\circ} \mathrm{C}$ for $36 \mathrm{~h}$, turbidity was determined to monitor cell growth [70]. The MIC was defined as the lowest concentration of the compounds inhibiting the yeast growth.

\section{Haemolytic assay}

It was essential first to study the degree of haemolysis produced by the test strain on $5.0 \%(\mathrm{w} / \mathrm{v})$ sheep red blood cells on blood agar plates. The haemolytic activity of the antifungal dialyzed concentrate on human erythrocytes was determined [71]. Human erythrocytes in $2 \%(\mathrm{v} / \mathrm{v})$ suspension were exposed to various concentrations of ACP ranging from 6.4 to $.00156 \mathrm{mg} \mathrm{ml}^{-1}$ at $37^{\circ} \mathrm{C}$ for $1 \mathrm{~h}$. The cells were peletted at $1,000 \mathrm{rpm}$ for $10 \mathrm{~min}$ and the supernatant was collected to determine the absorbance at $450 \mathrm{~nm}$ using a UV Visible Spectrophotometer (Shimadzu). In negative control sets, erythrocyte suspension and PBS buffer was used whereas in positive controls, lysis buffer was used for completely lysing the erythrocytes. The percentage haemolysis was calculated and plotted against the concentration of ACP to determine the dose cytotoxic to human erythrocytes. The percentage of intact erythrocytes was calculated using the following formula.

\section{Percent of intact erythrocytes}

$=\left(1-\frac{\text { Absorbance of protein }- \text { Absorbance of } P B S}{\text { Absorbance of lysis buffer }- \text { Absorbance of PBS }}\right)$

$\times 100$

Percent of hemolysis $=100-($ percent of intact erythrocytes $)$

\section{Haemagglutination activity assay}

In view of the findings that dialyzed concentrate exhibits haemagglutination activity [72], a serial 2-fold dilution of a solution of ACP (6.4 to $0.0001 \mathrm{mg} \mathrm{ml}^{-1}$ ) was added in microtitre plates, wherein $100 \mu \mathrm{l}$ was mixed with $100 \mu \mathrm{l}$ of a $2.0 \%$ suspension of human red blood cells in PBS $(\mathrm{pH} 7.2)$ at $20^{\circ} \mathrm{C}$. The results were observed after about $1 \mathrm{~h}$ when the blank without dialyzed concentrate was fully sedimented to inspect whether the red blood cells had agglutinated in response to the antifungal protein.

\section{Amino acid sequencing}

The corresponding protein band that showed the zone of inhibition against Candida albicans was electro blotted to a $0.45 \mu \mathrm{m}$ Immobilon-P transfer membrane (Millipore). After blotting at $100 \mathrm{~mA}$ for overnight, the membrane was removed carefully from the cassette, washed three times with MilliQ water to remove glycine, and then stained for $30 \mathrm{sec}$ with a freshly prepared solution of $0.1 \%$ Coomasie brilliant blue R-250 in $40 \%$ methanol and $1.0 \%$ acetic acid. The blot was then destained in 50\% methanol until bands were visible and background clear. The PVDF membrane was then dried sandwiched between clean tissue papers. The stained band of interest was tightly cut out and washed six times in MillQ water and subjected to Edman degradation. 
The N-terminal sequencing was performed on a Protein sequencer, Model 494 Procise (Applied Biosystems, USA) with $140 \mathrm{C}$ analyzer at Protein Sequencing Facility, IOWA State University, USA. The primary amino acid sequence obtained was entered into BLAST to search for peptides with similar sequences.

\section{Mass spectrometry}

The purified antimicrobial peptide was analyzed by matrixassisted laser desorption and ionization-time of flight mass spectrometry by using a 4000 Q TRAP Mass Spectrometer (Proteomics International, Nedlands Australia) equipped with an ion source with visualization optics and an $\mathrm{N}_{2}$ laser $(337 \mathrm{~nm})$. Protein samples were trypsin digested and peptides extracted according to standard techniques [73]. All digestion reactions were done in $50 \mathrm{mmol} \mathrm{NH}_{4} \mathrm{HCO}_{3}(\mathrm{pH}$ 8.5) at room temperature and with an enzyme-to-peptide ratio of 1:40 (wt/wt). Peptides were analyzed by electrospray ionisation mass spectrometry using the Ultimate 3000 nano HPLC system [Dionex] coupled to a $4000 \mathrm{Q}$ TRAP mass spectrometer (Applied Biosystems) with a capillary cap voltage of $1,750 \mathrm{~V}$. Tryptic peptides were loaded onto a C18 PepMap100, $3 \mu \mathrm{m}$ [LC Packings] and separated with a linear gradient of water/acetonitrile $/ 0.1 \%$ formic acid (v/v). MS/MS spectra were analyzed using PEAKS Studio Version 4.5 SP2 [Bioinformatics Solutions]. The mass data collected during LC/MS/MS analysis were processed, converted into mgf files, and compared against the Ludwig NR database by using a local MASCOT server.

The three most abundant peptides, preferably doubly charged ions, corresponding to each MS spectrum were selected for further isolation and fragmentation. The MS/MS scanning was performed in the ultrascan resolution mode at a rate of change in the $\mathrm{m} / \mathrm{z}$ of $26.000 \mathrm{~s}^{-1}$.

\section{Abbreviations \\ AMP: Antimicrobial peptide; ACP: Anticandida protein; MTCC: Microbial type culture collection; NCIM: National collection of industrial microorganisms; MDR: Multidrug resistance; DI: Diabetic isolate; WI: Wild type isolate; MGYP: Malt extract glucose, yeast extract, peptone; mTSB: Modified trypticase soya broth; IMTECH: Institute of microbial technology; PMSF: Phenyl- methane-sulfonyl-fluoride; MWCO: Molecular weight cut-off.}

\section{Competing interests}

Both authors declare that there is no conflict of interests.

\section{Authors' contributions}

RMS carried out this research (bench work) as part of his PhD work and UR designed several experiments, helped in writing the manuscript and overall supervision of the study. Both authors read and approved the final manuscript.

\section{Acknowledgements}

This work was financially supported by the Council of Scientific and Industrial Research (CSIR), and University Grants Commission (UGC), New Delhi, India. The facility provided by BITS Pilani KK Birla Goa Campus is thankfully acknowledged. The authors are grateful to Professor Dibakar Chakrabarty and Vidhya Lakshmi for their kind support. Author RMS was supported by a CSIR Senior Research fellowship.
Received: 23 December 2011 Accepted: 21 June 2012

Published: 4 July 2012

\section{References}

1. Hoffmann JA: Phylogenetic perspectives in innate immunity. Science 1999, 284(5418):1313-1318.

2. Bulet $P$, Stocklin $R$, Menin L: Anti-microbial peptides from invertebrates to vertebrates. Immunol Rev 2004, 198:169-184.

3. Otvos L Jr: Insect peptides with improved protease-resistance protect mice against bacterial infection. Protein Sci 2000, 9(4):742-749.

4. Vigers AJ, Roberts WK, Selitrennikoff CP: A new family of plant antifungal proteins. Mol Plant Microbe Interact 1991, 4:315-323.

5. Sela-Buurlage MB, Ponstein AS, Bres-Vloemans SA, Melchers LS, Van Den Elzen P, Cornelissen B: Only specific tobacco (Nicotiana tabacum) chitinases and [beta]-1,3- glucanases exhibit antifungal activity. Plant Physiol 1993, 101:857-863.

6. Ho VS, Wong JH, Ng TB: A thaumatin-like antifungal protein from the emperor banana. Peptides 2007, 28:760-766.

7. Wong $J H$, Zhang $X Q$, Wang HX, Ng TB: A mitogenic defensin from white cloud beans (Phaseolus vulgaris). Peptides 2006, 27:2075-2081.

8. Ng TB, Parkash A: Hispin, a novel ribosome inactivating protein with antifungal activity from hairy melon seeds. Protein Expr Pur 2002, 26:211-217.

9. Wang SY, Wu JH, Ng TB, Ye XY, Rao PF: A non-specific lipid transfer protein with antifungal and antibacterial activities from the mung bean. Peptides 2004, 25:1235-1242.

10. Yang $X$, Li J, Wang $X$, Fang W, Bidochka MJ, She R, Xiao Y, Pei Y: Psc-AFP, an antifungal protein with trypsin inhibitor activity from Psoralea corylifoliaseeds. Peptides 2006, 27:1726-1731.

11. Daniel JS, Christopher AH, Carol M, Sibley CM: Current and Emerging Azole Antifungal Agents. Clin Microbiol Rev 1999, 12(1):40-79.

12. Gozalbo D, Roig P, Villamón E, Gil ML: Candida and Candidiasis: the cell wall as a potential molecular target for antifungal therapy. Curr Drug Targets Infect Disord 2004, 4:117-135.

13. Mishra NN, Tulika P, Neeraj S, Anurag P, Rajendra P, Dwijendra KG, Randhir S: Pathogenicity and drug resistance in Candida albicans and other yeast species. Acta Microbiol Immunol Hung 2007, 54(3):201-235.

14. Priscu JC, Adams EE, Lyons WB, Voytek MA, Mogk D, Brown R, McKay CP Takacs CD, Welch KA, Wolf CF, Kirshtein JD, Avci R: Geomicrobiology of subglacial ice above Lake Vostok. Antarct Sci 1999, 286:2141-2144.

15. De Vuyst L, Foulquie Moreno MR, Revets $\mathrm{H}$ : Screening for enterocins and detection of hemolysin and vancomycin resistance in enterococci of different origins. Int J Food Microbiol 2003, 84:299-318.

16. Leroy F, De Vuyst L: Bacteriocin production by Enterococcus faecium RZS C5 is cell density limited and occurs in the very early growth phase. Int J Food Microbiol 2002, 72:155-164.

17. Pantev A, Valcheva R, Danova S, Ivanova I, Minkov I, Haertle T: Effect of enterococcin A 2000 on biological and synthetic phospholipid membranes. Int J Food Microbiol 2003, 80:145-152.

18. Audisio MC, Oliver G, Apella MC: Protective effect of Enterococcus faecium J96, a potential probiotic strain, on chicks infected with Salmonella pullorum. J Food Prot 2000, 63:1333-1337.

19. Shekh RM, Singh P, Singh SM, Roy U: Antifungal activity of Arctic and Antarctic bacteria isolates. Polar Biol 2011, 34:139-143.

20. Cheng S, McCleskey FK, Gress MJ, Petroziello JM, Liu R, Namdari H, Beninga K, Salmen A, DelVecchio VG: A PCR Assay for Identification of Enterococcus faecium. J Clinical Microbiol 1997, 35:1248-1250.

21. Balla E, Dicks LMT, Du Toit M, van der Merwe MJ, Holzapfel WH: Characterization and cloning of the genes encoding enterocin 1071 A and enterocin 1071B, two antimicrobial peptides produced by Enterococcus faecalis BFE 1071. Appl Env Microbiol 2000, 66:1298-1304.

22. Franz CMAP, Grube A, Herrmann A, Abriouel H, Starke J, Lombardi A, Tauscher B, Holzapfel WH: Biochemical and genetic characterization of the two-peptide bacteriocin enterocin 1071 produced by Enterococcus faecalis FAIR-E 309. Appl Env Microbiol 2002, 68:2550-2554.

23. Maldonado-Barragan A, Caballero-Guerrero B, Jimeneza E, Jimenez-Diaz R, Ruiz-Barba JL, Rodriguez JM: Enterocin C. a class Ilb bacteriocin produced by $E$. faecalis C901, a strain isolated from human colostrums. Int J Food Microbiol 2009, 133:105-112.

24. Ennahar S, Asou Y, Zendo T, Sanomoto K, Ishizaki A: Biochemical and genetic evidence for production of enterocins $A$ and $B$ by Enterococcus faecium WHE 81. Int J Food Microbiol 2001, 70:291-301. 
25. Matejuk A, Leng Q, Begum MD, Woodle MC, Scaria P, Chou ST, Mixson AJ: Peptide based Antifungal Therapies against Emerging Infections. Drugs Fut 2010, 35(3):197.

26. Giraffa G: Functionality of enterococci in dairy products. Int I Food Microbiol 2003, 88:215-222.

27. Hugas M, Garriga M, Aymerich MT: Functionalty of enterococci in meat products. Int J Food Microbiol 2003, 88:223-233.

28. Lucca AJD, Walsh TJ: Antifungal Peptides, Novel Therapeutic Compounds against Emerging Pathogens. Antimicrob Agents Chemother 1999, 43:1-11.

29. Landy M, Warren GH, Roseman SB, Colio LG: Bacillomycin, 584 an antibiotic from Bacillus subtilis active against pathogenic fungi. Proc Soc Exp Biol Med 1948, 67:539-541.

30. Mhammedi A, Peypoux F, Besson F, Michel G: Bacillomycin F, a new antibiotic of iturin group isolation and characterization. J Antibiot 1982, 35:306-311.

31. Billstein SA: How the pharmaceutical industry brings an antibiotic drug to market in the United States. Antimicrob Agents Chemother 1994, 38:2679-2682

32. Latoud C, Peypoux F, Michel G, Genet R, Morgat JL: Interactions of antibiotics of the iturin group with human erythrocytes. Biochim Biophys Acta 1986, 856:526-535.

33. Ostrosky-Zeichner L: Deeply invasive candidiasis. Infect Dis Clin North Am 2002, 16(4):821-835.

34. Venkatesan P, Perfect JR, Myers SA: Evaluation and management of fungal infections in immunocompromised patients. Dermatol Ther 2005, 18(1):44-57.

35. Prasad R, Kapoor K: Multidrug resistance in yeast Candida. Int Rev Cytol 2005, 242:215-248

36. Chandrasekar PH, Cutright J, Manavathu E: Efficacy of voriconazole against invasive pulmonary aspergillosis in a guinea-pig model. $J$ Antimicrob Chemother 2000, 45(5):673-676.

37. Perea $\mathrm{S}$, Patterson TF: Antifungal resistance in pathogenic fungi. Clin Infect Dis 2002, 35(9):1073-1080.

38. Hernandez S: Caspofungin resistance in Candida albicans: correlating clinical outcome with laboratory susceptibility testing of three isogenic isolates serially obtained from a patient with progressive Candida esophagitis. Antimicrob Agents Chemother 2004, 48(4):1382-1383.

39. Hakki M, Staab JF, Marr KA: Emergence of a Candida krusei isolate with reduced susceptibility to caspofungin during therapy. Antimicrob Agents Chemother 2006, 50(7):2522-2524.

40. Thompson GR 3rd: Development of caspofungin resistance following prolonged therapy for invasive candidiasis secondary to Candida glabrata infection. Antimicrob Agents Chemother 2008, 52(10):3783-3785.

41. Tabbene O, Kalai L, Slimene IB, Karkouch I, Elkahoui S, Gharbi A, Cosette $P$, Mangoni ML, Jouenne T, Limam F: Anti-Candida effect of bacillomycin D-like lipopeptides from Bacillus subtilis B38. FEMS Resear let 2011, 316:108-114.

42. Yanagida F, Chen $Y$, Onda T, Shinohara T: Durancin L28-1A, a new bacteriocin from Enterococcus durans L28-1, isolated from soil. Lett Appl Microbiol 2005, 40:430-435.

43. De Kwaadsteniet M, Todorov SD, Knoetze H, Dicks LMT: Characterization of a 3944 Da bacteriocin, produced by Enterococcus mundtii ST15, with activity against Gram-positive and Gram-negative bacteria. Int J Food Microbiol 2005, 105:433-444.

44. Ferreira AE, Canal N, Morales D, Fuentefria DB, Corcao G: Characterization of Enterocins Produced by Enterococcus mundtii Isolated from Humans Feces. Brazilian Arch Biol Technol 2007, 50:249-258.

45. Losteinkit C, Uchaiyama K, Ochi S, Takaoka T, Nagahisa K, Shioya S: Characterization of Bacteriocin N15 produced by Enterococcus faeciumN15 and Cloning of the Related Genes. J Biosc Bioeng 2001, 91:390-395.

46. Atrih A, Rekhif N, Moir AJG, Lebrihi A, Lefebvre G: Mode of action, purification and amino acid sequence of plantaricin C19, an anti-Listeria bacteriocin produced by Lactobacillus plantarum C19. Int J Food Microbiol 2001, 68:93-104.

47. Hernandez D, Cardell E, Zarate V: Antimicrobial activity of lactic acid bacteria isolated from Tenerife cheese: initial characterization of plantaricin TF711, a bacteriocin-like substance produced by Lactobacillus plantarum TF711. J Appl Microbiol 2005, 99:77-84.

48. Bizani D, Brandelli A: Characterization of a bacteriocin produced by a newly isolated Bacillus sp. Starin 8A. J Appl Microb 2002, 93:512-519.

49. Jianhua X, Rijun Z, Changjiang S, Yaoqi G: Isolation and characterization of a bacteriocin produced by an isolated Bacillus subtilis LFB112 that exhibits antimicrobial activity against domestic animal pathogens. African j Biotechnol 2009, 8:5611-5619.

50. Hastings W, Sailerm M, Johnsonk K, Roy KL, Vederas JC, Stiles ME: Characterization of Leucocin A-UAL 187 and cloning of the bacteriocin gene from Leuconostoc gelidum. J Bacteriol 1991, 173:7491-7500.

51. Kim DH, Lee $D G$, Kim KL, Lee $Y$ : Internalization of tenecin 3 by a fungal cellular process is essential for its fungicidal effect on Candida albicans. Eur J Biochem 2001, 268:4449-4458.

52. Bulet $P$, Cociancich $S$, Dimarcq JL, Lambert J, Reichhart JM, Hoffmann D, Hetru C, Hoffmann JA: Insect immunity: Isolation from a coleopteran insect of a novel inducible antibacterial peptide and of new members of the insect defensin family. J Biol Chemistry 1991, 266:24520-24525.

53. Otero-Gonzalez AJ, Magalhaes BS, Garcia-Villarino M, Lopez-Abarrategui C, Sousa DA, Dias SC, Franco OL: Antimicrobial peptides from marine invertebrates as a new frontier for microbial infection control. FASEB 2010, 24:1320-1334.

54. Rodriguez A, Villegas E, Satake H, Possani LD, Corzo G: Amino acid substitutions in an alpha-helical antimicrobial arachnid peptide affect its chemical properties and biological activity towards pathogenic bacteria but improve its therapeutic index. Amino Acids 2011, 40:61-68.

55. Cordes FS, Bright JN, Sansom MSP: Proline-induced distortions of transmembrane helices. J Mol Biol 2002, 323:951-960.

56. Capinera JL: Encyclopedia of Entomology. 2nd edition. Springer; 2008.

57. Dempsey CE, Bazzo R, Harvey TS, Syperek I, Boheim G, Campbel ID: Contribution of proline-14 to the structure and actions of melittin. FEBS Lett 1991, 281:240-244

58. Garver P, Muriana M: Purification and Partial Amino Acid Sequence of Curvaticin FS47 a Heat-Stable Bacteriocin produced by Lactobacillus curvatus FS47. Appl Env Microbiol 1994, 60(6):2191-2195.

59. Lee DG, Kim PI, Park YK, Woo ER, Choi JS: Design of novel plants peptide analogs with potent fungicidal activity, based on PMAP-23 antimicrobial peptide isolated from porcine myeloid. Biochem Biophys Res Commun 2002, 293(1):231-238

60. Holo H, Nilssen O, Nes IF: Lactococcin A, a new bacteriocin from Lactococcus lactis sub sp. cremoris: isolation and characterization of the protein and its gene. J Bacteriol 1991, 173:3879-3887.

61. Muriana PM, Klaenhammer TR: Purification and partial characterization of lactacin F, a bacteriocin produced by Lactobacillus acidophilus 11088 . Appl Environ Microbiol 1991, 57:114-121.

62. Oppegard C, Fimland G, Thorbek L, Nissen-Meyer J: Analysis of the twopeptide bacteriocins lactococcin $\mathrm{G}$ and enterocin 1071 by site-directed mutagenesis. Appl Environ Microbiol 2007, 73:2931-2938.

63. Shai Y: Mode of action of membrane active antimicrobial peptides. Biopolymers (Peptide Sciences) 2002, 66:236-248.

64. Gennaro R, Zanetti M, Benincasa M, Podda E, Miani M: Proline-rich antimicrobial peptides from animals: structure, biological functions. Curr Pharmacol Des 2002, 8(9):763-778.

65. Cintas LM, Casaus P, Holo H, Hernandez PE, Nes IF, Havarstein LS: Enterocins L50A and L50B, two novel bacteriocins from Enterococcus faecium L50, are related to staphylococcal hemolysins. J Bacteriol 1998 , 180:1988-1994.

66. Wong JH, Hao J, Cao Z, Qiao M, Xu H, Bai Y, Ng TB: An antifungal protein from Bacillus amyloliquefaciens. J Appl Microbiol 2008, 105:1888-1898.

67. Nakayama J, Takanami Y, Horii T, Sakuda S, Suzuki A: Molecular Mechanism of Peptide-Specific Pheromone Signaling in Enterococcus faecalis, Functions of Pheromone Receptor TraA and Pheromone-Binding Protein TraC Encoded by Plasmid pPD1. J Bacteriol 1998, 180:449-456.

68. Anne-sophie L, Gemert EV, Marie-Pierre C-C: Analysis of the Bacteriolytic Enzymes of the Autolytic Lactococcus lactis sub sp. cremoris Strain AM2 by Renaturing Polyacrylamide Gel Electrophoresis: Identification of a Prophage-Encoded Enzyme. Appl Env Microbiol 1998, 64:4142-4148.

69. Schagger H, Von Jagow G: Tricine-sodium dodecyl sulfate-polyacrylamide gel electrophoresis for the separation of proteins in the range from 1 to 100 kDa. Anal Biochem 1987, 166:368-379.

70. Hasan MF, Das R, Khan A, Hasan MS, Rahman M: The determination of antibacterial and antifungal activities of Polygonum hydropiper (L.) Root Extract. Adv Biol Res 2009, 3:53-56.

71. Yadav V, Mandhan R, Dabur R, Chhillar AK, Gupta J, Sharma GL: An antifungal fraction from Escherichia coli. J Med Microbiol 2005, 54:375-379. 
72. Liu Y, Chen Z, Ng TB, Zhang J, Zhou M, Song F, Lu F, Liu Y: Bacisubin, an antifungal protein with ribonuclease and hemagglutinating activities from Bacillus subtilis strain B-916. Peptides 2007, 28:553-559.

73. Bringans S, Eriksen S, Kendrick T, Gopalakrishnakone P, Livk A, Lock R, Lipscombe R: Proteomic analyses of the venom of Heterometrus longimanus (Asian black scorpion). Proteomics 2008, 8:1081-1096.

doi:10.1186/1471-2180-12-132

Cite this article as: Shekh and Roy: Biochemical characterization of an anti-Candida factor produced by Enterococcus faecalis. BMC Microbiology 2012 12:132.

\section{Submit your next manuscript to BioMed Central and take full advantage of:}

- Convenient online submission

- Thorough peer review

- No space constraints or color figure charges

- Immediate publication on acceptance

- Inclusion in PubMed, CAS, Scopus and Google Scholar

- Research which is freely available for redistribution 